\title{
PEMBINAAN WANITA TUNA SUSILA MELALUI \\ PANTI SOSIAL KARYA WANITA “ANDAM DEWI" \\ DI SUKARAMI
}

\author{
Oleh \\ Yuhasnil dan Firman Firman \\ Jurusan Bimbingan dan Konseling FIP Universitas Negeri Padang \\ Email“firman@konselor@org
}

\section{A. Pendahuluan}

Perubahan sosial dalam masyarakat tidak jarang berdampak negatif terhadap masalah sosial, seperti pelacuran dan prositusi. Pelacuran atau prostitusi merupakan problema sosial yang sejak lama mendapat perhatian para ilmuan sosial. Hal ini disebabkan karena pelacuran termasuk "profesi tertua di dunia" yang bukan dianggap sebagai lapangan kerja yang sah (Hull, Sulistyaningsih, dan Jones, 1997: ix). Pelacuran juga termasuk masalah perilaku menyimpang (deviant behavior) yang mempunyai dampak besar terhadap tata kehidupan masyarakat.

Kartono (1997: 9) menjelaskan perilaku menyimpang diartikan sebagai tingkah laku yang menyimpang dari tendensi sentral atau ciri-ciri karakteristik rata-rata dari masyarakat kebanyakan. Tingkah laku ini sering dipersamakan dengan tingkah laku abnormal atau tingkah laku yang tidak selaras dan tidak bisa diterima oleh masyarakat pada umumnya, dan tidak sesuai dengan norma sosial yang ada. Selanjutnya, Kartono (1997: 13) menjelaskan pelacuran dapat digolongkan ke dalam perilaku 
menyimpang tersembunyi, karena masalah ini tidak kentara dan sulit diamati.

Pelacuran dalam kajian ini merupakan perbuatan atau praktek bisnis yang memperdagangkan hubungan kelamin di luar pernikahan dengan tujuan memperoleh keuntungan ekonomi serta kenikmatan seksual. Berbagai istilah tentang pelacur dikemukakan masyarakat, diantaranya adalah prostitusi; sementara orangnya (para wanitanya) dikenal dengan julukan hostes, pelacur, pekerja seks komersial (PSK), dan wanita tuna susila (WTS).

Daniel Dhakidae (1976: 36) menjelaskan pelacuran disebabkan oleh aspek psikologis, ekonomis, dan biologis-seksual. Penyebab pelacuran yang paling dominan berkaitan dengan masalah sosiopsikologis dan sosio-ekonomis, atau masalah keluarga.

Berdasarkan data statistik pada Panti Sosial Karya Wanita (PSKW) Andam Dewi Sukarami terdapat 39 orang eks. WTS yang sedang mendapatkan proses pembinaan atau rehabilitasi (data hasil grand tour tanggal 27 Nopember 2003). Dari data tersebut ternyata pada umumnya mereka berasal dari Sumatera Barat (Minangkabau), dan hanya empat orang yang berasal dari luar Sumatera Barat. Deskripsi WTS yang dibina di Panti Sosial Karya Wanita Sukarami Solok terlihat pada tabel berikut ini.

Tabel 1

Deskripsi WTS yang Sedang Dibina di Panti Sosial Karya

Wanita Sukarami Solok

\begin{tabular}{|c|c|c|}
\hline No. & Daerah Asal & Jumlah \\
\hline $\begin{array}{l}1 . \\
2 . \\
3 . \\
4 . \\
5 .\end{array}$ & $\begin{array}{l}\text { Sumatera Barat } \\
\text { Jambi } \\
\text { Bengkulu } \\
\text { Riau } \\
\text { Malaysia }\end{array}$ & $\begin{array}{r}35 \text { orang } \\
1 \text { orang } \\
1 \text { orang } \\
1 \text { orang } \\
1 \text { orang }\end{array}$ \\
\hline & Jumlah & 39 orang \\
\hline
\end{tabular}

Sumber: Diolah dari data statistik di PSKW Andam Dewi Sukarami 
Berdasarkan tabel tersebut di atas menunjukkan sebagian besar WTS yang dibina di Panti Sosial Karya Wanita Andam Dewi berasal dari Minangkabau. Sehubungan dengan hal itu, pernyataan sastrawan Abrar Yusra dalam sebuah novelnya berjudul Tanah Ombak (2002), dengan tokoh bernama Yasmi, seorang gadis cantik dari Luhak Nan Tigo (Luhak Tanah Datar, tempat asalnya adat Minang-kabau) ternyata juga berprofesi sebagai hostes. Sekalipun berupa karya fisksi, bukan berarti kisah tersebut hasil imajinasi belaka.

Sebuah petikan kalimat yang cukup dramatis pada halaman 72 , mantan wartawan Harian Singgalang itu menulis:

\begin{abstract}
"Ada hal yang menyiksaku, entah kenapa. Yaitu bahwa Yasmi berasal dari kawasan luhak Tanah Datar, tanah leluhur orang Minang. Malahan tak jauh dari negeri Sungai Tarab, yang dahulu tempat kedudukan kementerian adat Kerajaan Minangkabau yang beribu kota Pagaruyung, Batusangkar itu. Meskipun ikatan adat sudah longggar di mana-mana dibanding zaman dahulu, tapi semestinya pengaruh adat masih lebih kuat di luhak Tanah Datar, bahkan di negeri-negeri tertua, seperti negeri asal Yasmi. Maka benar-benar tak masuk akal bahwa Yasmi justu bekerja sebagai hostes! Suatu perbuatan yang jelas amat tercela di mata orang beradat yang memuliakan perempuan."
\end{abstract}

Di daerah Sumatera Barat sebagian besar berpenduduk orang Minang-kabau termasuk pemeluk agama Islam yang sangat teguh menjalankan ajaran agamanya. Konsepsi adat Minang secara jelas menetapkan landasan: "Adaik Basandi Sara', Sara' Basandi Kibullah", yang artinya: Adat bersendikan agama, agama bersendikan Kitabullah (Islam). Dalam arti kata praktek pelacuran atau profesi sebagai wanita tuna susila 
(WTS) bukan saja suatu perbuatan bezat yang dilarang oleh ajaran agama Islam, tetapi juga termasuk perbuatan aib dan malu, bukan saja bagi keluarga ataupun kampung, tetapi juga bagi sesama komunitas orang Minang.

Dalam mengantisipasi dan menangulangi munculnya masalah WTS di ranah Minang pada tahun 1977 diselenggarakan Seminar Penyusunan Pola Induk Pembangunan Bidang Kesejahteraan Sosial di Sumatera Barat yang melibatkan unsur-unsur perguruan tinggi, tokoh masyarakat, organisasi masyarakat, dan instansi-instansi pemerintahan terkait. Salah satu hasil rumusannya adalah merekomendasikan perlunya upaya-upaya pencegahan dan penanggulangannya masalah WTS. Sebagai realisasinya diminta kepada instansi terkait untuk melakukan razia-razia terhadap WTS, dan mendirikan panti rehabilitasi wanita tuna susila, serta mengalokasikan anggaran rutin dana Anggaran Pendapatan dan Belanja Daerah (APBD) sebesar Rp. 3 juta sebagai dana pembinaan.

Program rehabilitasi sosial terhadap wanita tuna susila dimaksudkan agar para WTS sungguh-sungguh ingin meninggalkan profesinya dan memi-liki keahlian serta keterampilan agar mendapatkan pekerjaan pengganti jika di kemudian hari kembali ke masyarakat (Terence H. Hull, 1997: 42).

Sebagai upaya mencegah perkembangan aktivitas prostitusi di Sumatera Barat (termasuk kegiatan terselubung), pada tahun 2001 yang lalu pemerintah daerah Propinsi Sumatera Barat mengeluarkan peraturan 
perundang-undangan berupa PERDA (Peraturan Daerah) Nomor 11 Tahun 2001 tentang Pencegahan dan Pemberantasan Maksiat. Peraturan daerah ini lazim disebut dengan "PERDA PEKAT" (Peraturan Daerah tentang Pemberantasan Penyakit Masyarakat). Tujuan utama pencegahan dan pemberantasan penyakit masyarakat tersebut, sebagaimana yang tercantum dalam pasal 3 adalah: (1) menerapkan prinsip dan filosofi Adat Basandi Sarak, Sarak Basandi Kitabullah, (2) melindungi masyarakat terhadap adanya berbagai bentuk kegiatan dan/atau perbuatan maksiat, (3) mendukung penegakan hukum yang optimal terhadap ketentuan Peraturan Perundang-undangan yang berhubungan dengan kegiatan dan/atau perbuatan maksiat yang terjadi, dan (4) meningkatkan peranserta masyarakat dalam mencegah dan memberantas terjadinya serta meluasnya perbuatan maksiat.

Sekalipun belum dikatakan efektif, namun dengan peraturan daerah tersebut aparat keamanan mempunyai pegangan dan landasan kuat untuk malakukan tindakan serta mengadakan razia dan penggerebekan terhadap hotel atau tempat-tempat yang dicurigai melakukan praktek maksiat. Bagi mereka yang terjaring, setelah diklarifikasi dan wawacarai, akhirnya diserahkan ke Panti Sosial Karya Wanita (PSKW) Andam Dewi di Sukarami, Kabupaten Solok untuk seterusnya dilakukan pembinaan.

Program pembinaan terhadap wanita tuna susila di Sumatera Barat dirintis sejak tahun 1977 dan baru terrealisasikan pada tahun 1981, yakni 
dengan didirikannya Panti Rehabilitasi Wanita (PRW) Andam Dewi , Panti Sosial Andam Dewi saat ini berubah nama menjadi Panti Sosial Karya Wanita (PSKW) Andam Dewi Sukarami Solok. Dalam panti sosial ini para WTS mendapatkan pembinaan dan pelatihan dari pemerintah, dengan suatu harapan mereka menyadari perbuatannya dan kembali pada harkat serta martabatnya sebagai manusia di tengah masyarakat. Di samping itu mereka juga dibekali sejumlah pengetahuan dan keterampilan yang kelak dapat menjadi pekerjaan (profesi) pengganti setelah kembali ke masyarakat.

Program pelayanan dan rehabilitasi terhadap wanita tuna susila di Panti Sosial Karya Wanita (PSKW) Andam Dewi Sukarami adalah sebagai berikut: (1) penerimaan klien atau para WTS; (2) pendataan identitas dan registrasi; (3) bimbingan fisik, seperti membentuk kharakter atau penanaman disiplin serta olah raga; (4) bimbingan mental, seperti ceramah agama, membaca Al-Quran, shalat berjamaah, menanamkan budi pekerti; (5) bimbingan sosial, baik secara individu dan kelompok maupun bimbingan sosial masyarakat; (6) bimbingan keterampilan, seperti menjahit, menyulam, membordir, home industri, pertanian, perkebunan, dan lain-lain; dan (7) penyaluran, bimbingan lanjutan, dan terminasi (Dinas Sosial, 2001).

Tahap penyaluran dalam pembinaan dimaksudkan adalah program rehabilitasi yang dilakukan dengan kegiatan pelayanan dan pembinaan sosial untuk mengembalikan para bekas WTS kembali ke masyararakat 
atau menempatkannya ke sektor-sektor usaha/kerja produktif sesuai dengan jenis keahlian dan keterampilannya. Tahap bimbingan lanjutan adalah upaya rehabilitasi dengan cara meninjau kembali bagaimana hasil proses pembinaan terhadap para bekas WTS yang sudah kembali ke masyarakat. Sementara pada tahap terminasi adalah tahap pembinaan dengan jalan memberikan tindakan/ kegiatan pemberian bantuan , pemecahan masalah dan pengembangan para bekas WTS yang sudah memiliki kemampuan menyesuaikan diri dengan nilai-nilai atau normanorma yang berlaku di masyarakat.

Berdasarkan data hasil "grand tour" yang dilakukan di Dinas Sosial Propinsi Sumatera Barat (dilakukan pada tanggal 5 Nopember 2003) dan di Panti Sosial Karya Wanita (PSKW) Andam Dewi di Sukarami (tanggal 27 Nopember 2003) ternyata banyak diantara para WTS yang sedang menjalani program pembinaan sudah beberapakali terjaring dan mengikuti program pembinaan di PSKW Andam Dewi Sukarami.

Bertitik tolak dari masalah tersebut menarik untuk ditelusuri lebih lanjut bagaimanakah pembinaan yang dilakukan di PSKW Andam Dewi Sukarami sehingga proses pembinaan yang dilaksanakan tidak berjalan secara efektif dan memenuhi sasaran. Sebab panti rehabilitasi dimaksudkan bagaimana membina para WTS agar dapat menjalani kehidupan norma seperti layaknya wanita lainnya. 


\section{B. Metode Penelitian}

Penelitian ini menggunakan pendekatan kualitatif, dengan lokasi penelitian adalah Panti Sosial Karya Wanita (PSKW) Andam Dewi di Sukarami, Kabupaten Solok. Jumlah informan sengaja tidak dibatasi, tetapi akan berhenti jika pertanyaan sudah terjawab dan tidak ditemukan lagi informasi-informasi baru yang signifikan. Pada tahap awal peneliti berangkat dari informan kunci, kemudian terus berlanjut ke informan lain sampai informasi yang dibutuhkan sudah mencukupi. Sumber informasi adalah pembina dan WTS yang dibina di Panti Sosial Karya Wanita Andam Dewi Sukarami. Pengumpulan dana menggunakan teknik wawancara, partisipan observasi dan analisis dokumen. Analisis data dilakukan secara induktif, dengan mengikti pola Miles dan Huberman (1992), dengan langkah-langkah: (1) reduksi data, (2) penyajian data, dan (3) penarikan kesimpulan.

\section{Temuan dan Pembahasan}

\section{Temuan}

a. Pembinaan Terhadap Wanita Tuna Susila Di Panti Sosial Karya Wanita (Pskw) Andam Dewi Sukarami

Pembinaan bekas Wanita Tuna Susila di Panti Sosial Karya Wanita Andam Dewi mengikuti petunjuk pelaksanaan (juklak) pelayanan dan rehabilitasi sosial yang telah digariskan Departemen Sosial Republik Indonesia. Bentuk pembinaan yang telah digariskan tersebut adalah : 
1) Pembinaan Fisik dan Kesehatan

Kegiatan pembinaan fisik dan kesehatan di Panti Sosial Karya Wanita Andam Dewi ditujukan untuk menjaga dan memulihkan kesehatan serta kebugaran fisik klien. Jenis kegiatan yang dilakukan, antara lain : Senam Kesegaran Jasmani (SKJ) yang dilaksanakan bersamaan dengan acara apel pada jam 07.45 sampai dengan 08.15 WIB setiap harinya selama lebih kurang 60 menit.

Di samping acara SKJ, dilaksanakan kegiatan olahraga yang terjadual setiap hari, selama 60 menit (yakni pukul $08.00-$ 09.00 WIB). Cabang olahraga yang dilaksanakan sesuai dengan sarana dan prasarana yang tersedia, yaitu bola volli. Olahraga yang tidak terjadual juga sering dilakansakan pada sore hari, sesuai dengan permintaan para klien.

Pembinaan fisik dan kesehatan yang lain adalah bimbingan pemulihan kesehatan, yakni konsultasi kesehatan secara individu atau kelompok. Untuk program kegiatan ini ,PSKW Andam Dewi mengadakan koordinasi dengan mendatangkan petugas dan tenaga kesehatan dari Puskesmas Kecamatan Gunung Talang. Pada jadwal tertentu juga didatangkan tenaga penyuluh kesehatan dari Dinas Kesehatan Kota Solok dan Padang, seperti penyuluhan tentang alat reproduksi, bahaya penyakit HIV/AIDS, dan lain-lain. 
2) Bimbingan Mental dan Spiritual

Bimbingan mental dan spritual ditujukan untuk meningkatkan rasa keimanan dan ketaqwaan serta bimbingan mengenai sikap mental dan kepribadian para klien. Jenis kegiatan yang dilakukan, diantaranya adalah: (1) shalat berjamaah di mushalla, (2) belajar mengaji atau baca tulis Al-Quran, dan (3) menyelenggarakan wirid pengajian dan ceramah keagamaan, baik dari Ustadz dari PSKW atau yang sengaja diundang dari luar. Khusus untuk belajar mengaji secara rutin disampaikan oleh dibimbing oleh dua orang tenaga honorer dengan status suami istri dan tinggal menetap di lokasi PSKW.

3) Bimbingan Sosial

Kegiatan bimbingan sosial merupakan bentuk kegiatan pertolongan yang dilakukan kepada klien. Jenis kegiatan bimbingan sosial (baik bimbingan secara individu, bimbingan kelompok, maupun bimbingan sosial masyarakat) yang dilakukan untuk membantu, memulihkan, serta mengembangkan tingkah laku positif para klien sehingga mereka mau dan mampu melakukan fungsi dan peranan sosialnya secara wajar dan dapat menjalin relasi dengan anggota keluarga dan masyarakat.

Bimbingan sosial individu (perorangan) diarahkan untuk mengatasi berbagai permasalahan unik yang dialami oleh masingmasing klien. Bimbingan sosial kelompok dilaksanakan dalam 
bentuk kelompok tolong-menolong (self-help group), kelompok penyembuhan (therapeutic group), kelompok sosialisasi (sosialisation group), serta kelompok rekreasi. Sementara bimbingan sosial masyarakat dilakukan dengan mendatang tokoh masyarakat, tokoh adat, pejabat lemabaga sosial/instansi pemerintah, serta bimbingan pergaulan dengan masyarakat sekitarnya.

Menyangkut soal bimbingan psikologi secara periodik dilaksanakan setiap hari Sabtu selama lebih kurang 90 menit dan waktu-waktu tertentu, di mana PSKW Andam Dewi mendatangkan tenaga ahli tetap seorang psikolog yang bertugas di Kantor Pemerintah Kabupaten Solok. Untuk kegiatan bimbingan norma-norma sosial budaya yang normatif dilakukan oleh instruktur (pembina) dari dalam, seperti kegiatan Dinamika Kelompok, Hubungan Antar Manusia dan Budi Pekerti.

4) Bimbingan atau Pelatihan Keterampilan Kerja

Pelaksanaan kegiatan bimbingan atau pelatihan keterampilam kerja dimaksudkan sebagai suatu sarana untuk memberikan pengetahuan, kecakapan, dan keterampilan kepada para klien yang dipersiapkan, sehingga dikemudian hari dapat bekerja dan berusaha jika kembali ke masyarakat seperti sediakala.

Bentuk bimbingan atau pelatihan keterampilan kerja yang diberikan adalah keterampilan menjahit baju, keterampilan bordir, keterampilan sulaman benang emas, serta keterampilan industri 
rumah tangga (home industri). Instruktur tetap untuk keterampilan bordir dan sulaman benang emas adalah seorang pengrajin bordir yang berasal dari Gunung Talang serta pegawai tetap dari PSKW. Sementara untuk ketempilan home industri dilakukan setiap hari Sabtu selama 90 menit dengan instruktur tetap.

5) Resosialisasi

Kegiatan resosialisasi mencakup hal-hal sebagai berikut: (1) pemantapan kesiapan klien untuk kembali pada kehidupan yang normatif di lingkungan keluarga, masyarakat, dan dunia kerja; (2) pemantapan kesiapan keluarga, masyarakat dan dunia kerja untuk menerima kembali keberadaan (existence) klien di lingkungan yang sama seperti warga masyarakat yang lainnya; dan (3) pemantapan kesiapan klien untuk melakukan kegiatan usaha sebagai sumber mata pencaharian.

6) Penyaluran

Kegiatan penyaluran merupakan proses tahapan pelayanan dan rehabilitasi sosial yang diarahkan kepada para klien untuk kembali dalam kehidupan masyarakat atau menempatkan mereka pada sektor-sektor usaha atau kerja produktif, sesuai dengan keterampilan kerja yang dimiliki.

Berdasarkan wawancara terungkat proses kegiatan kegiatan penyaluran diharapkan para klien mendapatkan mata pencaharian 
yang layak sebagai sumber penghasilan keluarga dalam memperbaiki kualitas hidupnya. Panti sosial bukan saja bertanggung jawab dalam bentuk penyiapan para klien terhadap usaha-usaha ekonomis produktif, tetapi juga dalam bentuk penyerahan paket bantuan stimulus serta pelaksanaan penyaluran." (Wawancara pada tanggal 31 Mei 2004).

7) Bimbingan Lanjut dan Terminasi

Tahap bimbingan lanjut merupakan tahapan pelayanan dan rehabilitasi sosial terhadap para klien yang dilaksanakan setelah satu atau dua bulan ke luar dari panti sosial. Kegiatan ini dimaksudkan sebagai upaya pendampingan untuk memantapkan kemandirian klien dalam kehidupan keluarga, masyarakat, dan lapangan kerja.

Setelah mengadakan supervisi serta konsultasi pengembangan pergaulan para klien, maka tahap akhir proses pembinaan dan rehabilitasi sosial adalah kegiatan terminasi. Proses ini merupakan suatu tindakan atau kegiatan pengakhiran atau pemutusan secara resmi dalam proses pemberian bantuan, pemecahan masalah atapun pengembangan kepada klien, yang dinilai sudah berhasil atau sudah mempunyai kemampuan dalam menyesuaikan diri dengan nilai-nilai atau norma-norma yang berlaku di masyarakat lingkungannya. 
Berdasarkan wawancara dengan pengelola Panti Sosial Karya Wanita Andam Dewi, terungkap tahapan pembinaan dan rehabilitasi sosial merupakan tahap yang paling sulit dan pihak panti sosial banyak menghadapi kendala. Hal ini disebabkan karena baik para klien maupun keluarganya merasa enggan untuk dikunjungi oleh pihak panti sosial. Para klien dan keluarga merasa malu jika anaknya atau salah seorang diantara keluarganya diketahui pernah memiliki profesi sebagai pelacur oleh masyarakat sekitarnya.

Berdasarkan wawancara dengan WTS yang di bina di Panti Sosial Karya Wanita Andam Dewi, terungkap pembinaan yang telah diterima di PSKW selama enam bulan tidak begitu efektif bagi kehidupan mereka setelah kembali ke masyarakat. Baik itu bimbingan norma-norma sosial, bimbingan mental keagamaan, maupun bimbingan keterampilan yang mereka dapatkan selama pembinaan. Masalah yang sulit dihadapi setelah kembali ke masyarakat adalah: (1) tidak adanya modal awal kerja, (2) tidak mendapat tempat di masyarakat, di mana mereka dianggap sampah yang membahayakan suami-suami dan anak laki-laki, (3) tidak adanya lapangan kerja yang mau menerima eks. WTS, (4) adanya ancaman dari orang-orang yang tidak dikenal agar hidup kembali ke dunia pelacuran. 
Dengan demikian pembinaan terhadap WTS di Panti Sosial Karya Wanita Sukarami, dilakukan dalam bentuk : (1) pembinaan fisik dan jasmani, (2) bimbingan mental dan spritual, (3) bimbingan sosial, (4) bimbingan atau pelatihan keterampilan kerja, (5) resosialisasi, (6) penyaluran, (7) bimbingan lanjutan dan terminasi.

b. Permasalahan dalam proses pembinaan terhadap Wanita Tuna Susila di Panti Sosial Karya Wanita (PSKW) Andam Dewi Sukarami.

Selama pembinaan WTS, Panti Sosial Karya Wanita Andam Dewi mengalami kesulitan memperoleh data yang akuran dari WTS sebagai klien yang dibina di Panti Sosial Karya Wanita Andam Dewi, menyangkut dengan : karakateristik pribadi, latar belakang keluarga, pendidikan, ekonomi, serta kondisi sosial psikologis masing-masing WTS sebagai klien, latar belakang penyebab terjerumus menjadi WTS. Data klen tersebut sangat dibutuhkan dalam pemberian layanan dan proses rehabilitasi di panti sosial.

Berdasarkan data tersebut sebenarnya para pembina/instruktur dapat menentukan bagaimana strategi dan bentuk pembinaan yang akan diberikan secara individual dan kelompok. Hal ini sesuai dengan tuntutan prinsip dan standarisasi proses pemberian layanan dan bimbingan yang telah ditetapkan oleh Departemen Sosial RI. Para eks. WTS sering merahasiakan 
data identitas diri (termasuk nama, alamat dan tempat asalnya). Kenyataan demikian berpengaruh terhadap tahap-tahap pembinaan yang akan diberikan.

Berdasarkan wawancara dengan pembina WTS di Panti Sosial Karya Wanita Andam Dewi, ditemukan WTS sampai di sini (maksudnya: PSKW) tidak mau jujur dan langsung terbuka mengemukakan identitas dirinya. Tidak saja nama, tetapi juga alamatnya disebutkan dengan menyebut alamat apa saja secara sembarangan, sehingga begitu dilakukan penjajakan samasekali tidak ada yang bernama seperti yang disebutkan. Hingga sekarang saja masih banyak diantara klien yang tidak bersedia menyebutkan nama lengkapnya secara jelas. Baru nanti setelah dua atau tiga kali ditanya dengan cara pendekatan individual dan dalam waktu yang tidak formal, para klien mau berkata jujur dan terus terang" (Wawancara tanggal 30 Mei 2004).

Permasalahan yang paling menyulitkan lagi bagi PSKW menerima anggota baru tanpa adanya proses verbal yang disertai dengan data yang lengkap. Berapa orang yang tertangkap saat razia dilakukan, sesampai di PSKW, WTS tersebut tutup mulut dan sulit mengenali karakteristik secara pribadi. Kesulitan memperoleh data berakibat kepada kesulitan dalam menetapkan strategi pembinaan secara individual.Tidak jarang WTS yang dibina di PSKW dilakukan secara kelompok, yang kadang kala 
strategi digunakan tidak dapat menyentuh kebutuhan secara individual.

Proses pembinaan WTS di PSKW yang telah digariskan menurut Juklak harus bersifat pelayanan, pendampingan, secara berkelanjutan, serta dilakukan sesuai dengan kebutuhan dan permasalahan yang dihadapi para klien. Prakteknya, apa yang dituntut dalam petunjuk pelaksanaan tersebut tidak dapat dilaksanakan. Hal ini mengingat daya tampung PSKW hanya sekitar 40-50 orang, sementara apa yang terjadi selama ini terus membludak melebihi daya tampung yang ada. Tambah lagi, sesuai dengan ketentuan lamanya kegiatan pembinaan adalah selama 6 (enam) bulan. Di samping itu para eks. WTS yang akan mengikuti pembinaan juga tidak datang secara serentak sehingga tidak memungkinkan melakukan tugas pembinaan secara kasuistis dan sistem klasikal sesuai lamanya mereka mengikuti proses pembinaan. Berdasarkan hasil wawancara dengan WTS di PSKW terungkap proses dan mekanisme pembinaan seperti ini cenderung membosankan dan tidak banyak manfaatnya.

Selama proses pembinaan dan rehabilitasi di PSKW Andam Dewi, partisipasi dan keikutsertaan orang tua atau keluarga sangat penting. Sejalan dengan pedoman pelayanan dan rehabilitasi sosial terhadap eks. WTS, kegiatan dan proses pembinaan akan berhasil secara efektif apabila terdapat koordinasi 
serta kerjasama yang baik antara petugas pembinaan dengan para orang tua atau keluarga. Kenyataan yang ditemui, sebagian besar orang tua atau mamak dari para klien sangat jarang sekali mengunjungi anak-kemanakannya yang sedang dikarantinakan di PSKW Andam Dewi. PSKW telah berupaya untuk menjalin kerjasama dengan mengundang para orang tua atau keluarga yang terdekat, tetapi umumnya tidak banyak yang memenuhi undangan/panggilan.

Para eks. WTS yang sedang mendapatkan pembinaan di PSKW tergolong pelacur kelas rendahan. Mereka pada umumnya tamat/pernah duduk di bangku SD atau SLTP, dan masih terdapat juga beberapa orang yang samasekali tidak tahu tulis baca alias buta huruf. Sehingga besar dugaan bahwa para WTS yang terjaring dan dikarantinakan di PSKW hanyalah mereka yang berasal dari kelas rendahan, sementara para pelacur kelas menengah ke atas setelah diproses dan adanya jaminan oleh sejumlah oknum akhirnya mereka dibebaskan.

Selain itu banyak juga diantara para klien yang bisa membaca Al-Quran dan shalat karena mendapat materi pembinaan di bidang mental spritual. Seperti yang diakui oleh WTS yang sedang di bina di PSKW bahwa mereka selama ini tidak tahun membaca Al-Quran dan tidak pernah melaksanakan 
sholat. Mereka pertama kali menyentuh Kitab Suci itu dan baru melaksanakan sholat karena sudah diajari di PSKW.

Petugas PSKW mengungkapkan bertugas di panti sosial ini merupakan profesi yang penuh resiko, demikian pernyataan yang sering diungkapkan oleh para pegawai di PSKW. Sekalipun para eks. WTS terjaring dan dikarantinakan selama enam bulan di PSKW tetapi jaringan yang bekerja (apakah itu bodyguard dan germo-nya) di bidang profesi bisnis pelacuran tersebut masih tetap berupaya bagaimana "membebaskan" atau "mengeluarkan" para eks. WTS dengan berbagai cara dan strateginya.

Berdasarkan wawancara dengan pembina di PSKW mengungkapkan: "Kami di sini sudah kenyang dengan sejumlah teror dan ancaman agar mengeluarkan salah seorang klien, bahkan tidak jarang juga yang membujuk serta menjanjikan sejumlah imbalan untuk pembebasan seseorang. Ada yang mengatasnamakan dirinya berasal dari pejabat ini dan ada pula yang menyebut dirinya dari aparat keamanan. Tetapi tidak satu pun diantara mereka berani langsung datang ke sini untuk menuntut pembebasan serta memberikan jaminan agar para eks. WTS tidak beroperasi lagi di luar".

Kisah lain yang sangat tragis dialami oleh Drs.S (Pembina di PSKW) saat mengantar pulang seorang eks. WTS asal Jawa Barat. Ketika masa pembinaan telah selesai maka salah seorang 
yang mengaku orang tuanya menghubungi PSKW (melalui telepon) agar diantar ke Teluk Bayur kemudian berangkat ke Pulau Jawa. Setelah dilakukan timbang terima dan mobil yang mengaku orang tuanya tadi berangkat menuju pelabuhan, datang lagi orang tua sebenarnya dari eks. WTS sesuai dengan waktu dan tempat yang telah ditentukan sebelumnya. Saat itu kami memang ketelodor. Kami menyangka itu orang tuanya, karena setelah kami tanyakan persis sesuai dengan data yang ada. Karena melihat sang orang tua sedih melihat anaknya, dan sang anak juga juga sudah mau bertobat dan ingin pulang bersama orang tuanya, akhirnya kami cari akal. Saya menyamar sebagai tamu di Kafe di Kota Padang dan saya ingin mem-booking si anak berapa saja asal bisa di bawa ke luar. Akhirnya berhasil, dan rasanya peristiwa yang saya alami ketika itu persis seperti kisah di film saja. Kata pembina tersebut.

Sekalipun pembinaan yang dilakukan adalah dalam bentuk "karantina", sesuai dengan ketentuan dan prinsip-prinsip pelayanan dan rehabilitasi sosial PSKW tidak diperbolehkan melarang adanya kunjungan dari pihak keluarga, apakah itu orang tua kandung, saudara, atau famili terdekat asalkan prosedur dan waktu kunjungan sesuai dengan ketentuan yang berlaku. Lamanya waktu kunjungan ditentukan sekitar 15 menit dan terlebih dahulu mendapatkan izin dari petugas. Kunjungan hanya diperbolehkan 
pada waktu siang hari di tempat pertemuan yang telah disediakan, yakni di pesanggrahan yang terletak di dekat pintu masuk atau depan kantor. Tamu baru diizinkan masuk setelah melalui pemeriksaan dari petugas Satpam (satuan pengamanan) yang menunjukkan surat-surat dari Kapolsek setempat (Kecamatan Gunung Talang) dan mendapat persetujuan dari petugas piket dari pegawai PNS. Selama waktu kunjungan selalu mendapat pengawasan oleh petugas keamanan dari jauh, dan akan memperoleh peringatan jika waktu yang telah disediakan sudah habis.

Seleksi dan pengamanan terhadap kunjungan ini sering mengalami sejumlah masalah. Hal ini disebabkan karena tidak jarang diantara mereka yang mengadakan kunjungan bukanlah berasal dari keluarga para klien. Petugas/pegawai seringkali mengalami kesulitan dalam melakukan seleksi dan pengamanan terhadap para tamu karena mereka yang berkunjung mendapatkan surat kunjungan dari kepolisian atau dinas sosial dari Propinsi maupun Kabupaten/Kota di Sumatera Barat, dan mereka mengaku sebagai saudara, abang, atau mamak dari para klien. Sekalipun para eks. WTS tidak diperbolehkan menggunakan Hand Phone (HP) tetapi ternyata mereka tetap menjalin hubungan komunikasi secara rutin dengan rekanan-rekanan dalam jaringan bisnis pelacuran. 
Dengan demikian dapat disimpulkan, permasalahan utama dialami PSKW dalam pembinaan WTS adalah masalah data tentang klien (WTS) yang dibina sangat terbatas. Para pembina mengalami kesulitan untuk menetapkan strategi dan pendekatan yang cocok untuk setiap individu dan kelompok WTS yang dibina karena keterbatasan data tersebut. Klien (WTS) yang baru ditangkap tanpa diiringgi oleh data yang jelas. Penetapan pola pembinaan menyulitkan karena mereka masuk tidak serentak. Pola pembinaan yang telah digariskan Departemen Sosial sebagain besar tidak dapat dilaksanakan. Fasilitas yang ada tidak dapat menampung jumlah WTS yang ada. Pendekatan yang digunakan tidak jarang membosankan bagi WTS yang dibina.Partisipasi keluarga dan karib kerabat lainnya dalam pembinaan sangatlah sedikit. Tingkat pendidikan WTS yang dibina pada umumnya sangat rendah dan bahkan ada yang buta huruf, bagi WTS kelas kakap tidak jarang lepas dari binaan karena adanya jaminan dari oknom tertentu. Gangguang dari muncikari dan backing para WTS tidak jarang mengancam ketenangan petugas dan pengelola dalam menjalankan tugas di PSKW Andam Dewi Sukarami.

\section{c. Solusi yang Dilakukan Mengatasi Permasalahan Pembinaan terhadap Wanita Tuna Susila di Panti Sosial Karya Wanita (PSKW) Andam Dewi Sukarami.}


Berdasarkan wawacara dengan pengelola PSKW Andam Dewi Sukarami mengungkapkan berbagai usaha dan strategi pembinaan yang dilakukan dengan suatu harapan bagaimana para eks. WTS bisa bertobat dan meninggalkan profesinya, serta hidup secara normal di tengah masyarakat. Segala bekal pembinaan yang diberikan, terutama keterampilan yang pernah diberikan diharapkan dapat menjadi modal dan keterampilan untuk berusaha dan berkerja sebagai sumber kehidupan di Masyarakat.Walaupun demikian apa yang diharapkan masih terdapat para eks. WTS yang menekuni prosesi lamanya dan kemudian terjaring oleh aparat keamanan serta masuk kembali untuk dibina di PSKW ini.

Dari masalah yang dihadapi selama pembinaan ada beberapa solusi yang pernah diupayakan, sehingga proses dan kegiatan pembinaan dapat berlangsung secara efektif. Diantara solusi yang dilakukan adalah sebagai berikut:

1) Bagi mereka yang telah berulangkali terjaring dan masuk karantina PSKW, kegiatan pertama yang dilakukan adalah membotaki rambut mereka. Hal ini dilakukan dengan harapan mereka jera dan malu kembali menekuni profesi itu setelah mendapatkan pembinaan dari PSKW. Waktu yang dijalani dalam karantina juga lebih lama dibanding dengan pada tahap pertama, yakni 
tahap kedua selama 1 (satu) tahun, sementara bagi yang ketiga kalinya berlangsung selama 3 (tiga) tahun.

Menghormati dan memperlakukan mereka seperti manusia biasa yang tidak luput dari kekhilafan dan kesalahan. Dalam pelaksanaannya, para eks WTS yang sedang dibina bukan saja disebut sebagai klien, tetapi juga mendapat perlakukan sebagai seorang siswa yang sedang mendapat pelajaran. Pakaian seragam kerja selama mengikuti proses pembinaan adalah mengenakan baju kurung dan pakai jilbab. Pakaian seragam seperti ini dimaksudkan agar terbiasa dengan pakaian-pakaian Islami yang sesuai dengan nilai-nilai dan norma-norma kehidupan yang berlaku serta tidak begitu mudah memperlihatkan bentuk tubuh serta aurat mereka selama proses pembinaan.

Selama proses dan kegiatan pembinaan eks. WTS juga tidak diperbolehkan memakai bedak, lipstick, dan jenis make up lainnya. Hal ini setidaknya dapat menghilangkan pikiran mereka dengan profesi sebelumnya yang begitu akrab dengan hal-hal yang bersifat berdandan.

Menjalin hubungan komunikasi dan koordinasi dengan para orang tua dan keluarga para eks. WTS, dan para orang tua serta niniak mamak diminta untuk banyak terlibat dalam proses pembinaan, setidaknya dalam hal konsultasi. 
Menjalin koordinasi dan kerja sama dengan pemerintah Kabupaten/Kota serta instansi-instansi terkait untuk secara bersama-sama dalam mendukung program pembinaan serta secara aktif berpartisipasi dalam menentukan bagaimana bentuk dan strategi pembinaan yang dijalankan.

Memperketat seleksi dan pengamanan terhadap waktu kunjungan. Kepada para tamu bukan saja diminta surat-surat resmi dari pejabat/instansi yang berwewenang, tetapi juga memperlihatkan surat dari kepala desa/kelurahan yang menyatakan bagaimana garis hubungan para tamu dengan orang yang dikunjungi. Seleksi dan pengamanan ini perlu dilakukakan agar terhindar dari kemungkinan-kemungkinan negatif bagi kehidupan para klien.

Solusi yang dilakukan di atas memang dirasakan jauh dari apa yang diharapkan agar pembinaan dapat berlangsung secara efektif. Masih banyak sebenarnya yang bisa dilakukan jika seluruh jajaran dalam masyarakat merasa dirinya mempunyai tanggung jawab dalam memberantas dunia pelacuran di wilayah Sumatera Barat. Akan tetapi, apa yang selama ini dirasakan memang masih jauh dari apa yang diharapkan.

Dengan demikian dapat disimpulkan solusi yang dilakukan PSKW dalam mengatasi permasalahan tersebut di atas, adalah adalah bagi yang berulang kali masuk untuk pembinaan tahap kedua 
dilakukan pembotkan rambut, masuk yang kedua kali, ditetapkan masa karantina selama dua tahun, begitu juga masuk yang ke tiga masa karantina selama tiga tahun. Selama proses pembinaan mereka diperlakukan sebagai murid dan tidak diperbolehkan untuk memakai perhiasan dan mic up serta berhubungan dengan memakai HP. PSKW melakukan koordinasi secara dekat dengan instansi serta keluarga dalam upaya pembinaan WTS lebih lanjut.

\section{Pembahasan}

Berdasarkan hasil penelitian ditemukan bentuk pembinaan di Panti Sosial Karya Wanita Andam Dewi dilakukan dalam bentuk : pembinaan fisik dan jasmani, bimbingan mental dan spritual, bimbingan sosial, Bimbingan atau pelatihan keterampilan kerja, resosialisasi, penyaluran, bimbingan lanjutan dan terminasi. Bentuk tersebut merupakan pola yang sudah baku digariskan Departemen Sosial. Penggunaan pola secara khas berdasarkan kondisi sosial geografis serta perbedaan individual WTS yang di bina di PSKW kurang jadi pertimbangan. Kondisi tersebut tidak jarang sebagai satu kendala dalam pelaksanaan pembinaan di PSKW Adam Dewi Sukarami.

Pola pembinaan WTS pada prinsipnya tidak bisa digeneralisasi untuk seluruh Indonesia, mengigat negara Indonesia majemuk dari etnik dan budaya. Soekanto (2001: 417) menjelaskan sebab-sebab terjadinya pelacuran haruslah dilihat dari faktor internal dan faktor 
eksternal. Yang dimaksud dengan faktor internal di sini adalah didorong oleh nafsu kelamin yang besar, sifat pemalas, dan keinginan yang besar untuk hidup mewah. Sementara, di antara faktor-faktor eksternal yang utama adalah faktor ekonomis, urbanisasi yang tak teratur, keadaan perumahan yang tidak memenuhi syarat dan sebagainya.

Kondisi tersebut tidak jarang sebagai penyebab timbulnya permasalahan dalam pembinaan WTS di PSKW, di antaranya adalah: data tentang klien (WTS) yang dibina. Para pembina mengalami kesulitan untuk menetapkan strategi dan pendekatan yang cocok untuk setiap individu dan kelompok WTS yang dibina. Klien (WTS) yang baru ditangkap tanpa diiringgi oleh data yang jelas dan penetapan pola karenatnanya menyulitkan karena mereka masuk tidak serentak.Pola pembinaan yang telah digariskan Departemen Sosial sebagain besar tidak dapat dilaksanakan. Fasilitas yang ada tidak dapat menampung jumlah WTS yang ada. Pendekatan yang digunakan tidak jarang membosankan bagi WTS yang dibina.Partisipasi keluarga dan karib kerabat lainnya dalam pembinaan sangatlah sedikit. Tingkat pendidikan WTS yang dibina pada umumnya sangat rendah dan bahkan ada yang buta huruf, bagi WTS kelas kakap tidak jarang lepas dari binaan karena adanya jaminan dari berbagai fihak. Gangguang dari muncikari dan backing para WTS tidak jarang mengancam ketenang petugas dan pengelola dalam menjalankan tugas. 
Tujuan program pembinaan WTS di PSKW tidak jarang kurang mencapai sasaran. Hull (1997: 42) menjelaskan program pembinaan dan rehabilitasi sosial yang diselenggarakan oleh pemerintah ditujukan bagi para wanita tuna susila yang sungguh-sungguh ingin meninggalkan pekerjaan (profesinya), tetapi tidak memiliki cukup keahlian atau mempunyai rasa percaya diri yang kuat sebagai bekal mencari pekerjaan yang layak. Salah satu kriteria untuk dapat mengikuti program pembinaan ini adalah: (a) wanita dengan status pelacur aktif berusia di bawah 35 tahun; (b) sehat jasmani, kecuali penyakit kelamin yang dapat disembuhkan sambil mengikuti program rehabilitasi; (c) berpikiran maju; (d) secara sukarela mau tinggal di asrama; (e) dapat mengikuti program sedikitnya enam bulan atau maksimum 12 bulan

\section{Kesimpulan dan Rekomendasi}

\section{Kesimpulan}

Berdasarkan temuan penelitian dapat disimpulkan, hal-hal berikut ini

a. Pembinaan terhadap WTS di Panti Sosial Karya Wanita Adam Dewi, menyangkut dengan: (1) pembinaan fisik dan jasmani, (2) bimbingan mental dan spritual, (3) bimbingan sosial, (4) Bimbingan atau pelatihan keterampilan kerja, (5) resosialisasi, (6) penyaluran, (7) bimbingan lanjutan dan terminasi. 
b. Permasalahan utama dialami PSKW dalam pembinaan WTS adalah masalah data tentang klien (WTS) yang dibina. Para pembina mengalami kesulitan untuk menetapkan strategi dan pendekatan yang cocok untuk setiap individu dan kelompok WTS yang dibina. Klien (WTS) yang baru ditangkap tanpa diiringgi oleh data yang jelas dan penetapan pola karenatnanya menyulitkan karena mereka masuk tidak serentak.Pola pembinaan yang telah digariskan Departemen Sosial sebagain besar tidak dapat dilaksanakan. Fasilitas yang ada tidak dapat menampung jumlah WTS yang ada. Pendekatan yang digunakan tidak jarang membosankan bagi WTS yang dibina.Partisipasi keluarga dan karib kerabat lainnya dalam pembinaan sangatlah sedikit. Tingkat pendidikan WTS yang dibina pada umumnya sangat rendah dan bahkan ada yang buta huruf, bagi WTS kelas kakap tidak jarang lepas dari binaan karena adanya jaminan dari berbagai fihak. Gangguang dari muncikari dan backing para WTS tidak jarang mengancam ketenang petugas dan pengelola dalam menjalankan tugas.

c. Solusi dilakukan dalam mengatasi permasalahan yang dialami PSKW dalam pembinaan WTS adalah bagi yang berulang kali masuk untuk pembinaan tahap kedua dilakukan pembotkan rambut WRS, masuk yang kedua kali, ditetapkan masa karantinaselama dua tahun, begitu juga masuk yang ke tiga masa karantina selama tiga tahun. Selama proses pembinaan mereka diperlakukan sebagai murid dan tidak diperbolehkan untuk memakai perhiasan dan mic up serta berhubungan dengan 
memakai HP. PSKW melakukan koordinasi secara dekat dengan instansi serta keluarga dalam upaya pembinaan WTS lebih lanjut.

2. Rekomendasi

Berdasarkan kesimpulan tersebut, dapat diajukan rekomendasi sebagai berikut :

1. Pola pembinaan di Panti Sosial Karya Wanita Sukarami masih bersifat Juklak dan Juknis dari Departemen Sosial serta ditemukan tidak sesuai dengan kebutuhan WTS berlatar belakang budaya Minangkabau. Dinas Sosial, Balitbang, Univ.Andalas, Univ.Negeri Padang dan IAIN diharapkan berkoordinasi untuk merumuskan pola pembinaan WTS di PSKW Andam Dewi Sukarami dalam mewujudkan adat basandi syarak, syarak basandikan kitabullah di Minangkabau.

2. PSKW mengalami kesulitan untuk memperoleh data setiap WTS yang dikareantinakan secara individual. Dinas Sosial dan PSKW dirasa perlu mengumpulkan data dengan menggunakan instrumen yang ada, seperti Inventory dan Test Psikologis, Wawancara dan observasi selama proses karantina untuk melengkapi data pribadi WTS yang dibina.

3. Data setiap WTS di PSKW Adam Dewi kurang jadi pertimbangan dalam pembinaan, karena strateginya bersifat kelompok. Dinas Sosial dan PSKW Andam Dewi dirasa perlu merumuskan dan 
melaksanakan pembinaan sesuai dengan karakteristik Individu WTS yang dibina.

4. Keamanan dan ketenteraman petugas yang mengelola dan membina WTS di PSKW untuk menjalankan tugas kurang mendapat perlindungan hukum dari ancaman backing dan oknom tertentu. Biro hukuman, Kepolisian dan DPRD dirasa perlu merumuskan aturan untuk melindunggi petugas dalam menengakkan Perda Pekat di Sumatera Barat.

5. Petugas yang membina WTS di PSKW Andam Dewi ditemukan kurang profesional. Dinas sosial diharapkan menseleksi dan menempatkan pekerja sosial yang sesuai dengan kebutuhan untuk pembinaan WTS di PSKW.

6. Partisipasi keluarga, masyarakat dan instansi terkait dalam melakukan pembinaan terahadap WTS di PSKW Andam Dewi ditemukan lemah. Binsospora, Diperindag, Dinas Pendidikan, Depag dirasa perlu merumuskan program yang terintegrasi sesuai dengan tugas fungsi masing-masing untuk melakukan pembinaan terhadap WTS di PSKW Andam Dewi Sukarami. 


\section{DAFTAR KEPUSTAKAAN}

\section{BUKU:}

Abdullah, Taufik (1966), "Adat dan Islam: Telaah Mengenai Konflik di Minangkabau", dalam Ahmad Ibrahim, Sharon Siddique, Yasmin Ibrahim (Ed.) Islam di Asia Tenggara, Jakarta: LP3ES.

(1983), "Studi Tentang Minangkabau", dalam A.A.Navis (ed.), Dialektika Minangkabau dalam Kemelut Sosial dan Politik, Padang: Genta Singgalang Press.

Benda-Beckmann, Franz von \& Keebet von (2000), "Transformasi dan Perubahan di Minangkabau" dalam Keebet von Benda-Beckmann, Goyahnya Tangga Menuju Mupakat: Peradilan Nagari dan Pengadilan Negeri di Minangkabau, Jakarta: PT Gramedia Widiasarana Indonesia bekerja sama dengan Perwakilan KITLV.

Berger, Peter L. \& Thomas Luckmann (1990), Tafsir Sosial atas Kenyataan, Jakarta: LP3ES.

Bogdan, Robert \& Steven J. Taylor (1993), Kualitatif, Dasar-Dasar Penelitian, Surabaya-Indonesia: Usaha Nasional.

Bogdan, Robert C. \& S.Knopp Biklen (1990), Riset Kualitatif untuk Pendidikan: Pengantar ke Teori dan Metode, Jakarta: PAU-PPAI.

Daradjat, Zakiah (1975), Pendidikan Agama dalam Pembinaan Mental, cetakan ketiga, Jakarta: Bulan Bintang.

Depdikbud (1988), Kamus Besar Bahasa Indonesia, Jakarta: Balai Pustaka.

Effendi, Sjofyan, Sjafri Sairin, M.Alwi Dahlan, Peny. (1992) Membangun Martabat Manusia: Peranan Ilmu-ilmu Sosial dalam Pembangunan, Yogyakarta: Gadjah Mada University Press.

Faisal, Sanafiah (1990). Penelitian Kualitatif, dasar-dasar dan aplikasi, Malang: Yayasan Asih Asah Asuh (YA3Malang).

Fakih, Mansour (2001), Sesat Pikir Teori Pembangunan dan Globalisasi, Yogyakarta: Insist Press \& Pustaka Pelajar, 2001.

Foucault, Michel (1997), Sejarah Seksualitas: Seks \& Kekuasaan, Jakarta: PT Gramedia Pustaka Utama.

Garna, Yudistira K. (1996), Ilmu-Ilmu Sosial: Dasar-Konsep-Posisi, Bandung: Program Pascasarjana Universitas Padjadjaran, 1996.

Gunawan, F.X. Rudy (2000), Mendobrak Tabu: Seks, Kebudayaan, dam Kebejatan Manusia, Yogyakarta: Galang Press.

Hull, Terence H., Endang Sulistyaningsih, Gavin W. Jones (1997), Pelacuran di Indonesia: Sejarah dan Perkembangannya, Jakarta: Pustaka Sinar Harapan dan The Ford Foundation.

Kartasasmita, Ginandjar (1996), Pembangunan Untuk Rakyat: Memadukan Pertum-buhan dan Pemerataan, Jakarta: PT Pustaka CIDESINDO.

Kartono, Kartini (1997), Patologi Sosial Jilid I, cetakan kelima, Yogyakarta: Kanisius. 
Kato, Tsuyoshi (1982), Matriliny and Migration: Evolving Minangkabau Traditions in Indonesia, Ithaca, London: Cornell University Press.

Koentjaraningrat, (1989), Metode-Metode Penelitian Masyarakatat, cetakan kesembilan, Jakarta: Universitas Indonesia.

(1997), Sejarah Teori Antropologi I, cetakan kedua, Jakarta: Universitas Indonesia (UI-Press).

dan Donal K. Emmerson, ed. (1985) Aspek Manusia dalam Penelitian Masyarakat, cet. kedua, Jakarta: Yayasan Obor Indonesia \& PT Gramedia.

Lauer, Robert H. (1993), Perspektif Tentang Perubahan Sosial, penerjemah: Alimandan, SU, cetakan kedua, Jakarta: Universitas Indonesia.

Lincoln, Yvonna S. \& Egon G. Guba (1995), Naturalistic Inquiry, Beverly Hills: Sage Publications, 1985.

Manning, Chris \& Peter van Diermen, ed. (2000), Indonesia di Tengah: Transisi Aspek-Aspek Sosial Reformasi dan Krisis, Yogyakarta: LKiS.

Miles dan Huberman (1992), Analisa Data Kualitatif, Jakarta: Universitas Indonesia.

Moleong, Lexy J. (2002) Metode Penelitian Kualitatif, cetakan ketujubelas, Jakarta: Remaja Rosdakarya.

Nasikun (2000), Sistem Sosial Indonesia, cetakan kesepuluh, Jakarta: Rajawali Press.

Nasroen, M., (1971), Dasar Falsafah Adat Minangkabau, cetakan kedua, Jakarta: Bulan Bintang.

Navis, A.A. (1986). Alam Terkembang Jadi Guru, Adat dan Kebudayaan Minangkabau, cetakan kedua, Jakarta: Pustaka Grafitipers.

(1999), Yang Berjalan di Sepanjang Jalan, Jakarta: PT Gramedia Widiasa-rana Indonesia.

Parsons, Talcott. Esei-Esei Sosiologi, Jilid 1. tp.: Aksara Persada, 1985.

-----. Esei-Esei Sosiologi, Jilid 2. tp.: Aksara Persada, 1986.

Poloma, Margareth M. (2000), Sosiologi Kontemporer, cetakan keempat, Jakarta: Rajawali Press.

Purnomo, Tjahyo \& Ashadi Siregar (1983), Dolly: Membedah Dunia Pelacuran Surabaya, Kasus Kompleks Pelacuran Dolly, Jakarta: Pustaka Grafitipers.

Ritzer, George (2002), Sosiologi Ilmu Pengetahuan Berparadigma Ganda, Jakarta: Rajawali Press. - \& Douglas J. Goodman. (2003). Teori Sosiologi Modern, Jakarta: Prenada Media.

Sanderson, Stephen K. (2000), Makro Sosiologi, Sebuah Pendekatan Terhadap Realitas Sosial, Jakarta: Rajawali Pers.

Robinson, Katrhyn (2001), "Wanita: Dikotomi Versus Keragaman" dalam Donald K. Emmerson (ed.) Indonesia Beyond Soeharto: Negara, Ekonomi, Masyarakat, Transisi, Jakarta: PT Gramedia Pustaka Utama. 
Shadily, Hassan (1957), Sosiologi untuk Masyarakat Indonesia, Jakarta: PT Pembangunan.

Soedjono, D. (1997), Pelacuran Ditinjau dari Segi Hukum dan Kenyataan dalam Masyarakat, Bandung: Karya Nusantara.

Soekanto, Soerjono (2001), Sosiologi Suatu Pengantar, cetakan ketigapuluh dua, Yogyakarta: Kanisius.

Sunarto, Kamanto. (2004), Pengantar Sosiologi, edisi ketiga, Jakarta: Fakultas Ekonomi Universitas Indonesia.

Soetrisno, Loekman (1997), Kemiskinan, Perempuan, dan Pemberdayaan, Yogyakarta: Kanisius.

Spradley, James P. (1997), Metode Etnografi, Yogyakarta: PT Tiara Wacana, 1997.

Usman Pelly dan Asih Menanti (1994), Teori-Teori Sosial Budaya, Jakarta: PPPTK-DIKTI.

Yusra, Abrar (2002), Tanah Ombak, Jakarta: Buku Kompas.

II. Tesis, Disertasi, Jurnal, Makalah, Dokumen, Terbitan Khusus

Abizar, Agus Irianto, Chatlinas Said (1999) "Buku Panduan Penulisan Tesis", Padang: Program Pascasarjana Uversitas Negeri Padang.

Ayatrohaedi (2003), "Pekerja Seks Komersial", dalam (kolom "Bahasa") Harian Kompas, 27 September.

Badang Kesejahteraan Sosial Nasional (2000). Standarisasi Pelayanan dan rehabilitasi Sosial Panti Sosial Karya Wanita (PSKW), Jakarta: Direktorat Pelayanan dan Rehabilitasi Tuna Sosial dan Korban Tindak kekerasan (PRTS \& KTK).

Departemen Sosial (1985), Petunjuk Pelaksanaan Penanganan Masalah Sosial Tuna Susila, Jakarta: Direktorat Jenderal Bina Rehabilitasi Sosial. (1991), Petunjuk Teknis Penanganan Masalah Sosial Tuna Susila, Jakarta: Direktorat Jenderal Bina Rehabilitasi Sosial.

(1984), Buku Putih: Rehabilitasi Sosial Tuna Susila, Jakarta: Direktorat Jenderal Bina Rehabilitasi Sosial, 1994.

(1986), Proses Rehabilitasi Sosial Melalui Sistem Perpantian, Jakarta: Direktorat Pelayanan dan Rehabilitasi Sosial Tuna Sosial Direktorat Jenderal Pelayanan dan Rehabilitasi Sosial.

(1996/1997), Petunjuk Forum Komunikasi Pekerja Sosial Masyarakat (FK-PSM), Jakarta: Direktorat Penyuluhan dan Bimbingan Sosial Direktorat Jenderal Bina Kesejahteraan Sosial.

- (2001), Modul Pelayanan dan Rehabilitasi Sosial di Panti Sosial Karya Wanita, Jakarta: Direktorat Pelayanan dan Rehabilitasi Sosial dan Korban Tindak Kekerasan Direktorat Jenderal Pelayanan dan Rehabilitasi Sosial.

(2002), Buku Pedoman Pelayanan Rehabilitasi Sosial Tuna Susila Panti, Jakarta: Direktorat Pelayanan dan Rehabilitasi Sosial Tuna Sosial Direktorat Jenderal Pelayanan dan Rehabilitasi Sosial. 
(2002), Buku Pedoman Pelayanan Rehabilitasi Sosial Tuna Susila Non Panti, Jakarta: Direktorat Pelayanan dan Rehabilitasi Sosial Tuna Sosial Direktorat Jenderal Pelayanan dan Rehabilitasi Sosial.

Dhakidae, Daniel (1976), "Industri Sex: Sebuah Tinjauan Sosio-Ekonomis", Majalah Prisma, No. 5, bulan Juni: Jakarta LP3ES.

Dinas Kesehatan dan Kesejahteraan Sosial Propinsi Sumatera Barat (t.tp), Kronologis Panti Sosial Karya Wanita "Andam Dewi" Sukarami Kabupaten Solok.

(2002), Profil Panti Sosial Karya Wanita Andam Dewi Solok.

Peraturan Daerah Propinsi Sumatera Barat Nomor: 11 Tahun 2001 tentang Pencegahan dan Pemberantasan Maksiat, Biro Hukum Sekretariat Daerah Propinsi Sumatera Barat, 2002.

Siagian, Tumona (1987), Penelitian tentang Pola Rehabilitasi dan Penanganan Pelacuran di Wilayah Daerah Ibukota Jakarta, Jakarta: Badan Penelitian dan Pengembangan Sosial, Departemen Sosial, 1987. 